\section{TERRITORIAL AGGRESSION BETWEEN A DRAGONFLY AND HUMMINGBIRD}

\author{
by Richard S. Miller, Saskatoon
}

A female Ruby-throated Hummingbird (Archilochus colubris) regularly visited flowers and $\mathrm{hummingbird}$ feeders in a garden in front of the University of $\mathrm{Sa} s \mathrm{katchew}$ a $\mathrm{n}$ Biology Department cabin on Fairy Island, Emma Lake, during the summer of 1965 . She established this as a feeding territory and chased other hummingbirds from it whenever they entered the clearing. This open area was also used as a feeding territory by dragonflies, mostly blue darners (Aeschnidae). On August 24 at 1:00 p.m. a male Aeschna lineata was observed chasing the female hummingbird from the clearing. The hummingbird returned in less than a minute and was chased away again, the dragonfly pursuing her to a height of 25 to 30 feet and over the roof of the cabin until she entered the woods. After four such encounters in about 10 minutes, the hummingbird stayed out of the territory and the dragonfly resumed its patrols.

A male $A$. lineata has a body length of about three inches and a wingspread of approximately four inches (Needham and Westfall, 1955) and, although not as stout, is comparable in these dimensions to a Rubythroated Hummingbird, which is three to three and one-half inches long (Peterson, 1947). It is interesting to note that these two species have certain behaviours in common. Both hover in flight, both ascend rapidly when pursued, and a chase continues until the intruder leaves the area of the territory. The flight path of a chase between hummingbirds is very like similar encounters between aeschnid's. Moore (1964) has observed that dragonflies, which are highly territorial, are especially aggressive toward members of their own species or other dragonflies which most nearly resemble them. Thus, the hovering flight, body size and metallic coloration of a hummingbird might easily provoke attack from a male Aeschna lineata.

\section{LITERATURE CITED}

Moore, N. W. 1964. Intra- and interspecies competition among dragonflies (Odonata). J. Anim. Ecol., $33: 49-71$.

Needham, J. G., and M. J. Westfall, Jr. 1955. A Manual of the Dragonflies of North America (Anisoptera). University of California Press, Berkeley. $615 \mathrm{pp}$.

Peterson, R. T. 1947. A Field Guide to the Birds. Houghton Mifflin Co., Boston. $290 \mathrm{pp}$.

\section{CROWS WARMING THEMSELVES AT A CHIMNEY}

by Emerson A. Stoner, Benicia, California

As a resident of California, I only infrequently have the opportunity to report an observation made while visiting our neighbouring country to the north. This fall my wife and I crossed the international boundary into British Columbia. While staying two nights at the Royal Towers Motor Hotel in New Westminster, we often looked out from our fifth floor window over the sweep of Fraser River country, where this fine river approaches the Strait of Georgia. Downward, on the roof of a lower building below us, was a moderately tall chimney from which in the mornings heavy clouds of smoke arose into the cold, damp, $40^{\circ}$ air - intermittently smoke, then heavy heat waves. Finally the smoke ceased and only the strong waves of heat issued from the chimney.

While we were casually enjoying the view for a short period on the early morning of October 19, 1965, a pair of Northwestern Crows (Corvus caurinus) alighted on the roof below, hopped about a bit, and flew to the chimney opening where they alighted. I feared they would get burned, as the heat waves appeared intense. However, they apparently had done this before, for one and then the other peered down the chimney opening. They walked along the top of the brick chimney, then one spread its wings widely, absorbing some of the heat and drying its feathers. Its partner performed likewise for a few minutes, after which both departed towards likely feeding grounds, as this was breakfast time for all of uis. 